\title{
Association of MTR A2756G Gene Polymorphism with Risk of Head and Neck Cancer Muhammad Tahir $^{1}$, Aamer Ali Khattak², Erum Monis ${ }^{3}$, Sana Gul ${ }^{4}$
}

\section{ABSTRACT}

Objective: To perform genotyping for MTR A2756G polymorphism and identification of risk factors associated with head and neck squamous cell carcinoma (HNSCC).

Study Design: Cross section, comparative study.

Place and Duration of Study: The study was carried out at the Department of Biochemistry of Quaid-i- Azam University, Islamabad from October 2014 to August 2015.

Materials and Methods: In this study, 292 diagnosed patients HNSCC and 324 normal individuals without any history of cancer were enrolled. Blood samples of patients and controls were collected in ethylenediamine tetra acetic acid (EDTA) and DNA was extracted using conventional method. All samples were genotyped for the MTR A2756G polymorphism using PCR-RFLP. Frequency of polymorphism was compared between HNSCC patients and controls. Multiple Logistic Regression (MLR) and chi-square test was performed to examine the association of MTR A2756G polymorphism with risk factor.

Results: Chi-square test of independence showed statistically significant difference among the variables of age, smoking and MTR A2756G genotype ( $p$-value<0.05). Multivariate analysis showed that smoking (adjusted OR, $3.7 ; 95 \% \mathrm{Cl}, 2.3-6.0$ ), age groups $41-50$ years (adjusted $\mathrm{OR}, 3.6 ; 95 \% \mathrm{Cl}, .9-6.7$ ) and $>60$ years (adjusted $\mathrm{OR}$, $3.5 ; 95 \% \mathrm{Cl}, 1.7-7.3$ ), MTR $2756 \mathrm{AG}$ genotype (adjusted $\mathrm{OR}, 2.1 ; 95 \% \mathrm{Cl}, 1.3-3.5$ ) is associated with increased risk of HNSCC.

Conclusion: The results suggest that the genetic polymorphism MTR A2756G is associated with the occurrence of HNSCC in the Pakistani population while the individuals between 40 to 50 years of age and those who are smokers are at a greater risk of developing HNSCC.

Key Words: Genetic Polymorphism, Head and Neck Cancer, Head and Neck Squamous Cell Carcinoma, MTR A2756G, PCR-RFLP.

How to cite this: Tahir M, Khattak AA, Monis E, Gul S. Association of MTR A2756G Gene Polymorphism with Risk of Head and Neck Cancer. Life and Science. 2020; 1(3): 103-108. doi: http://doi.org/10.37185/LnS.1.1.82

This is an Open Access article distributed under the terms of the Creative Commons Attribution License (http://creativecommons.org/licenses/by/4.0), which permits unrestricted use, distribution, and reproduction in any medium, provided the original work is properly cited

\section{Introduction}

Cancers that are commonly recognized as head and neck carcinoma (HNC) typically begin in the moist, mucosal surfaces inside the head and neck lining of ${ }^{1}$ Department of Biochemistry Beijing University of Technology, Beijing, China ${ }^{2}$ Department of Medical Lab Technology

University of Haripur, Haripur

${ }^{3}$ Department of Public Health

National University of Medical Sciences, Rawalpindi

${ }^{4}$ Department of Biological Sciences

National University of Medical Sciences, Rawalpindi

Correspondence:

Dr. Sana Gul

Assistant Professor, Biological Sciences

National University of Medical Sciences, Rawalpindi

E-mail: sana.gul@numspak.edu.pk

Funding Source: NIL; Conflict of Interest: NIL

Received: Nov 21, 2019; Revised: Jun 18, 2020

Accepted: Jul 01, 2020

103 squamous cells which cover the oral cavity, pharynx, hypopharynx, and larynx. The most frequent type of $\mathrm{HNC}$ is head and neck squamous cell carcinoma (HNSCC) which affects the mucosal lining of head and neck regions. ${ }^{1}$ HNC is ranked as the sixth most common malignancy in the world. ${ }^{2}$ In 2013, the number of new cases and deaths reported in the US were 53,640 and 11,520 , respectively. ${ }^{3} \mathrm{HNC}$ accounts for $40.1 \%$ of all malignant neoplasms and is reported as the second most common malignancy in Pakistan. ${ }^{4}$ $\mathrm{HNC}$ is a complex disorder involving multiple factors including genetic, environmental and mental stress. ${ }^{5}$ Alcohol and tobacco usage, human papilloma virus infection, folic acid and vitamin deficiencies also contributes to the occurrence of $\mathrm{HNC}^{6-8}$ The exact mechanism of pathogenesis of HNC is not yet fully known. $^{9}$ 
Folates in different forms are essential for cell division because of their role in purine and thymidine synthesis and DNA methylation. Hence folate deficiency or abnormal folate metabolism results in carcinogenesis. ${ }^{10,11}$ In purine and thymidine synthesis folate acts as a one-carbon donor. DNA methylation regulates gene expression. ${ }^{12}$ Epigenetic modifications in the DNA have functional roles from regulation of gene expression to chromatin structure stabilization. ${ }^{13}$ Four enzymes involved in control of folate metabolism are methionine synthase (MTR), methylenetetrahydrofolate reductase (MTHFR), thymidylate synthase (TS) and methionine synthase reductase (MTRR). ${ }^{14}$ In folate metabolism, 5, 10methylenetetrahydrofolate is irreversibly converted to 5-methyltetrahydrofolate by the action of MTHFR. Remethylation of homocysteine to methionine is catalysed by MTR, methyl donor in this reaction is 5methyltetrahydrofolate. (MTRR causes reductive methylation of vitamin B12 and activates MTR. In another reaction, TS uses the 5, 10 methylenetetrahydrofolate and converts deoxyuridylate to thymidylate (nucleotide synthesis). Polymorphisms in these genes involved in folate metabolism, are believed to increase the risk of cancer by altering methylation and DNA synthesis, consequently affecting the chromosomal structure and stability. ${ }^{6}$

1q43 is the location of MTR gene. ${ }^{15,16}$ This enzyme maintains normal intracellular methionine and homocystine concentrations. ${ }^{17}$ Molecular studies revealed that change from $A$ to $G$ ( $r s 1805087$ ) at position 2756 of MTR gene results in an amino acid substitution of aspartic acid to glycine (D919G). This substitution lowers MTR efficiency which in turn results in hyperhomocysteinemia. ${ }^{16,18}$

Many studies have explored the link between MTR A2756G polymorphism with breast cancer ${ }^{19}$, colon cancer $^{20}$, lung cancer ${ }^{21}$ and role of polymorphism in tumour development and treatment responses against cancer. $^{22}$ Several studies have reported association of MTR A2756G polymorphism with head and neck cancer, where genotypic frequencies of HNC patients and control individuals were compared. These studies concluded that the MTR 2756AG genotype significantly increases the risk of HNC. $^{23,24}$ In addition MTR 2756 AG or GG genotype is shown to be significantly associated with increased risk of laryngeal cancer. ${ }^{25}$ Contrary to these findings, another research group showed that MTR A2756G polymorphism is not associated with increased risk of head and neck cancer. ${ }^{26}$

Based on this contradictory literature, this study was designed to compare genotypes of MTR gene in HNSCC patients and normal individuals to investigate the association of this polymorphism in Pakistan.

\section{Materials and Methods}

\section{Patient Selection}

In this study 616 individuals were recruited, 292 HNSCC diagnosed patients and 324 control individuals without any history of cancer. Nuclear Medicine Oncology and Radiotherapy Institute (NORI), was the site for sample collection. Institutional ethical approval was obtained from Quaid-i-Azam University and NORI before starting the study. Blood samples ( $5 \mathrm{ml} /$ individual) of HNSCC patients and controls were collected with the informed consent of the participants. Blood samples were transferred to the research lab at Quaid-i-Azam University, Islamabad for further processing.

\section{DNA Extraction}

The standard phenol protocol already demonstrated was used for DNA isolation from blood. ${ }^{27}$ DNA samples were run on to $1 \%$ agarose gel electrophoresis for $30 \mathrm{~min}$ at $120 \mathrm{~V}$ in $10 \mathrm{X}$ TrisBorate-EDTA running buffer and visualizing under ultraviolet trans-illuminator.

\section{Genotyping}

To study the MTR A2756G polymorphism (rs1805087), polymerase chain reaction-restriction fragment length polymorphism (PCR-RFLP) was used. Primer 3 software was used to design primers for amplifying exon 26 of MTR gene. The primers used in this study were sense $5^{\prime}$ GCCCACTGAGTTTACCTTTTCC $3^{\prime}$ and anti-sense $5^{\prime}$ CCTGCCTCATGTCTCCATTT 3'. To amplify target DNA, a reaction mixture of $25 \mu \mathrm{L}$ was prepared containing $1.5 \mu \mathrm{L} \mathrm{MgCl} 2$ (25 mM), dNTPs (10 mM), forward and reverse primers $0.5 \mu \mathrm{L}(0.1 \mu \mathrm{M}), 0.5 \mu \mathrm{L}$ Taq DNA polymerase $(5 \mathrm{U} / \mu \mathrm{L}) 0.5 \mu \mathrm{L}, 1 \mathrm{X}(10 \mathrm{mM}) 2.5 \mu \mathrm{L}$ PCR buffer (10x), $1 \mu \mathrm{L}$ DNA template and $18 \mu \mathrm{L}$ PCR water. The conditions for thermal cycler were as follows: an initial denaturation at $96^{\circ} \mathrm{C}$ for $5 \mathrm{~min}$, followed by 35 rounds of $96^{\circ} \mathrm{C}$ at $1 \mathrm{~min}$ for denaturation, annealing at $60^{\circ} \mathrm{C}$ for 45 seconds, extension at $72^{\circ} \mathrm{C}$ for $1 \mathrm{~min}$ and a final extension of $5 \mathrm{~min}$ at $72^{\circ} \mathrm{C}$. PCR amplified 
product of 664 bp was confirmed on $2 \%$ agarose gel. The PCR product bp was digested with Haelll enzyme for $10 \mathrm{~min}$ at $37^{\circ} \mathrm{C}$ following manufacturer's instruction.

\section{Statistical Analysis}

Percentages of the total number of alleles and genotypes were calculated to determine frequencies. Pearson's chi-square test was applied to compare allelic frequencies of patients and controls with $P$ value $<0.05$ documented as significant. Genetic polymorphism and variables related interaction effect with HNSCC was determined using multiple logistic regression model. Models included genotype (reference: $A / A$ ), sex (reference: female), smoking (reference: non-smokers) and age group (reference: $<40$ Years), using the Statistical Package for the Social Sciences (SPSS) Version 6.0. Odds ratio $(\mathrm{OR})$ and at $95 \%$ confidence intervals $(95 \% \mathrm{Cl})$ were calculated and results were documented.

\section{Results}

The $292 \mathrm{HNSCC}$ patients had a male to female ratio of $2: 1$, mean age $46 \pm 12$. The 324 controls had male to female ratio of 3:1, mean age of $35 \pm 10$. Among the HNSCC patients $57 \%(n=166)$ had oral cavity cancer, $23 \%(n=68)$ had cancer of the larynx and $20 \%(n=58)$ had cancer of the pharynx. Patient from age group of 41-50 years had higher frequency of HNSCC $(n=194)$ and many participants among controls were tobacco users $(n=112)$. The electropherogram of digested products of the PCR-RFLP assay revealed three DNA band patterns as depicted in Figure 1, representing AA, AG, GG genotypes (Figure 1).

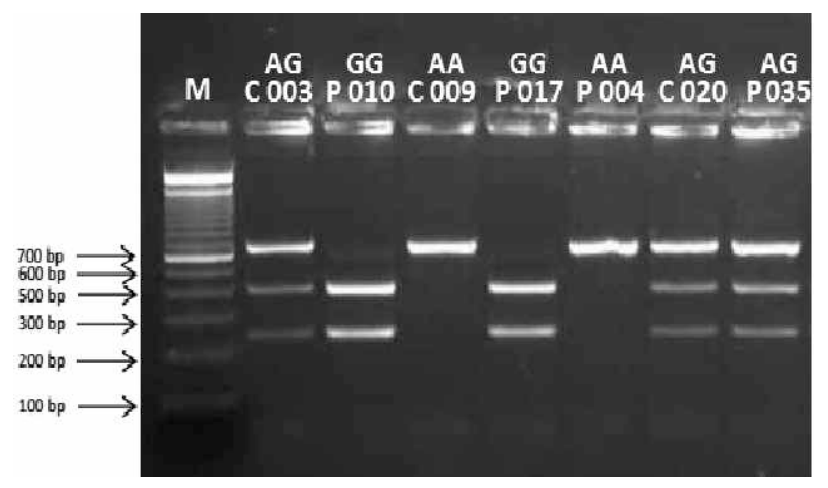

Fig 1: RFLP analysis of 664 bp fragment of MTR gene. C represents normal controls while $P$ indicates $H$ NSCC patient DNA. $M$ is a $100 \mathrm{bp}$ ladder. Presence of one DNA band on gel indicates AA genotype, three DNA bands indicate AG genotype and two DNA bands indicate GG genotype.
In HNSCC patients $A A, A G$ and $G G$ genotype frequencies for MTR A2756G polymorphism were $59 \%, 37 \%$ and $4 \%$ respectively and in control individuals $A A, A G$ and $G G$ genotype frequencies for MTR A2756G polymorphism were $76 \%, 22 \%$ and $2 \%$ respectively. The genotype frequencies for all investigated polymorphisms among controls $\left(\chi^{2}\right.$ test: $P=0.846)$ and $P$ patients ( $\chi^{2}$ test: $P=0.490$ ) were in Hardy-Weinberg equilibrium.

\begin{tabular}{|c|c|c|c|}
\hline Variables & $\begin{array}{l}\text { Patients (\%) } \\
(n=292)\end{array}$ & $\begin{array}{c}\text { Controls (\%) } \\
(n=324)\end{array}$ & $p$-value \\
\hline \multicolumn{4}{|l|}{ Gender } \\
\hline Male & 204 (69.9) & $248(76.5)$ & \multirow{2}{*}{0.185} \\
\hline Female & $88(30.1)$ & $76(23.5)$ & \\
\hline \multicolumn{4}{|l|}{ Age } \\
\hline$<40$ years & $54(18.5)$ & $124(38.3)$ & \multirow{4}{*}{$<0.001^{\star}$} \\
\hline $41-50$ years & $124(42.5)$ & $78(24.1)$ & \\
\hline $51-60$ years & $56(19.1)$ & $84(25.9)$ & \\
\hline$>60$ years & 58 (19.9) & $38(11.7)$ & \\
\hline \multicolumn{4}{|l|}{ Smoking } \\
\hline Smokers & $194(66.4)$ & $112(34.6)$ & \multirow{2}{*}{$<0.001^{*}$} \\
\hline Non -Smokers & $98(33.6)$ & $212(65.4)$ & \\
\hline \multicolumn{4}{|c|}{ MTR 2756 Genotypes } \\
\hline AA & $172(58.9)$ & $246(75.8)$ & \multirow{3}{*}{$0.003^{*}$} \\
\hline AG & $108(36.9)$ & $72(22.1)$ & \\
\hline GG & $12(4.2)$ & $06(2.1)$ & \\
\hline
\end{tabular}

${ }^{*} P$-value $<0.05$ (Two sided $\chi^{2}$ test

Chi-square test of independence analysis showed significant association ( $p$-value $<0.05$ ) of patients age (41-50 years), smoking status and MTR 2756 AG genotype with HNSCC, (Table 1). Further these variables were adjusted by performing multivariate analysis.

Multivariate analysis showed that smoking (adjusted OR, 3.7; $95 \% \mathrm{Cl}, 2.3-6.0$ ), age group $41-50$ years (adjusted $\mathrm{OR}, 3.6 ; 95 \% \mathrm{Cl}, 0.9-6.7$ ) and $>60$ years (adjusted OR, 3.5; 95\% Cl, 1.7-7.3) and MTR 2756AG (adjusted OR, 2.1; 95\% Cl, $1.3-3.5$ ) genotype is associated with increased risk of HNSCC (Table 2).

\section{Discussion}

HNC is a group of cancers comprising of cancer of larynx, oral cavity and pharynx. This is the sixth most frequent cancer globally. ${ }^{1,2}$ In the present study, among HNSCC patients male to female ratio was 2:1. The finding has also been reported in previous studies conducted in different populations ${ }^{23,28,29}$, while one study reported that male and females were affected by this cancer. ${ }^{30}$ In our study we found 


\begin{tabular}{|c|c|c|}
\hline Variables & OR (95 \% Cl) & $p$-value \\
\hline \multicolumn{3}{|l|}{ Smoking } \\
\hline Non-smokers & Reference & \\
\hline Smokers & $3.7(2.3-6.0)$ & $<0.001^{*}$ \\
\hline \multicolumn{3}{|l|}{ Gender } \\
\hline Female & Reference & \\
\hline Male & $1.0(0.5-1.8)$ & 0.18 \\
\hline \multicolumn{3}{|l|}{ Age } \\
\hline$<40$ years & Reference & \\
\hline 41 - 50 years & $3.6(1.9-6.73)$ & $<0.001^{*}$ \\
\hline $51-60$ years & $1.5(0.7-2.9)$ & 0.205 \\
\hline$>60$ years & $3.5(1.7-7.3)$ & $0.001^{*}$ \\
\hline \multicolumn{3}{|c|}{ MTR 2756 Genotypes } \\
\hline AA & Reference & \\
\hline AG & $2.1(1.3-3.5)$ & $0.003^{*}$ \\
\hline GG & $1.1(0.6-2.1)$ & 0.081 \\
\hline \multicolumn{3}{|c|}{ MTR 2756 Alleles } \\
\hline A & Reference & \\
\hline G & $1.9(1.2-3.5)$ & $0.002^{*}$ \\
\hline
\end{tabular}

$P$-value $<0.05$ (Multiple logistic regression)

that the incidence of HNSCC is more in age groups 41 -50 years and $>60$ years as previously reported by Northern Ireland Cancer Registry, 2010 and Welsh Cancer Intelligence and Surveillance Unit, 2014. This finding is suggestive that these age groups are a risk factor for onset of HNSCC. ${ }^{31}$ Incidence of oral cancer has increased while frequency of pharyngeal cancer has reduced in the past few years in many populations worldwide. Oral cancer has been reported as the most frequent cancer among the head and neck regions in England ${ }^{32}$ and Taiwan. ${ }^{33}$ Similar results have been observed in our study where the incidence of oral cancer was high among HNC patients. Alcohol and tobacco usage, in majority of cases $(90 \%)$, followed by human papilloma virus infection and nutrients deficiency are predisposing factors. ${ }^{28,34}$

Recent literature showed that low levels of folate play a role in the aetiology of $\mathrm{HNSCC}^{8,35,36}$ Folate is a vital nutrient, which play an important role in many biological processes like DNA synthesis, DNA repair, and DNA methylation (epigenetics). ${ }^{37}$ MTR gene which encodes MTR enzymeis responsible for catalysing the methylation of homocystine to methionine ${ }^{38}$, an important reaction that regulates normal homeostasis of methionine and intracellular homocystine concentrations. ${ }^{17}$ The functional activity of MTR in the presence of the MTR A2756G polymorphism has not been assessed in vitro. There is contradiction in studies related to changes in homocystine and folate levels. ${ }^{39-43}$ Some studies indicated that polymorphic homozygous MTR
2756GG genotype is associated with low levels of homocystine and high levels of folate. ${ }^{40,43}$ In some other studies it is reported that in the presence of this variant homocystine levels are high ${ }^{41}$ while it has also been reported that in the presence of this polymorphism homocystine levels do not changed. ${ }^{42}$ DNA methylation has been linked to MTR 2756AG or MTR 2756GG polymorphism with reduced level of Sadenosylmethionine which ultimately results in DNA hypomethylation $^{44}$ and several cancers to control tissues studies confirmed frequent overall genomic hypomethylation. ${ }^{45-48}$ Few studies reported the association between the MTR $2756 \mathrm{GG}$ genotype and DNA hypomethylation also in colorectal, breast, lung and cervix cancers. ${ }^{24,44,49,50}$

Research studies have suggested the association between risk of head and neck cancer and MTR 2756AG polymorphism ${ }^{23-25}$ while another study found no such association. ${ }^{26}$ In this study, it has been found that the polymorphic variant of MTR 2756 AG and MTR 2756 GG are associated with HNC. Statistical analysis showed that association with increased risk of HNC and MTR 2756 AG genotype which supports the findings of many researchers who reported this association. ${ }^{23-25}$

Our findings suggest that MTR 2756AG genotype is associated with increased risk of head and neck cancer and we suggest in vivo studies in cell lines or animal models should be done to evaluate the functional activity of this enzyme in the presence of 2756 AG polymorphism. Further investigation of altered expression and function of other genes involved in folic acid metabolism is required for better understanding of etiopathogenesis of HNSCC and to develop better anticancer strategies to control and treat the HNC.

\section{Acknowledgements}

We thank the study participants for their involvement in the study, and the anonymous reviewers for comments that substantially improved the manuscript. I greatly acknowledge NORI hospital for clinical sample collection and Quai-i-Azam University, Islamabad where all research work was carried out.

\section{REFERENCES}

1. Marur S, D'Souza G, Westra WH, Forastiere AA. HPVassociated head and neck cancer: a virus-related cancer 
epidemic. The lancet oncology. 2010; 11: 781-9.

2. Jemal A, Siegel R, Xu J, Ward E. Cancer statistics, 2010. CA: a cancer journal for clinicians. 2010; 60: 277-300.

3. Society AC. Cancer Facts \& Figures 2013.

4. Hanif M, Zaidi P, Kamal S, Hameed A. Institution-based cancer incidence in a local population in Pakistan: nine year data analysis. Asian Pac J Cancer Prev. 2009; 10: 227-230.

5. Abusail MS, Dirweesh AMA, Awad R, Salih A, Gadelkarim $\mathrm{AH}$. Expression of EGFR and p53 in Head and Neck Tumors among Sudanese Patients. Asian Pacific Journal of Cancer Prevention. 2013; 14:6415-8.

6. Kane MA. The role of folates in squamous cell carcinoma of the head and neck. Cancer detection and prevention. 2005; 29: 46-53.

7. Marcu LG, Yeoh E. A review of risk factors and genetic alterations in head and neck carcinogenesis and implications for current and future approaches to treatment. Journal of cancer research and clinical oncology. 2009; 135: 1303-14.

8. Pelucchi C, Talamini R, Negri E, Levi F, Conti E, Franceschi S, et al. Folate intake and risk of oral and pharyngeal cancer. Annals of Oncology. 2003; 14: 1677-81.

9. Mishra A, Meherotra R. Head and Neck Cancer: Global Burden and Regional Trends in India. Asian Pacific Journal of Cancer Prevention. 2014; 15: 537-50.

10. D'Alessio AC, Szyf M. Epigenetic tête-à-tête: the bilateral relationship between chromatin modifications and DNA methylation This paper is one of a selection of papers published in this Special Issue, entitled 27th International West Coast Chromatin and Chromosome Conference, and has undergone the Journal's usual peer review process. Biochemistry and cell biology. 2006; 84: 463-6.

11. Niculescu MD, Zeisel SH. Diet, methyl donors and DNA methylation: interactions between dietary folate, methionine and choline. The Journal of nutrition. 2002; 132: 2333S-5S.

12. Pufulete $\mathrm{M}, \mathrm{Al}$-Ghnaniem R, Leather AJ, Appleby P, Gout S, Terry $C$, et al. Folate status, genomic DNA hypomethylation, and risk of colorectal adenoma and cancer: a case control study. Gastroenterology. 2003; 124:1240-8.

13. Ehrlich $\mathrm{M}$. The ICF syndrome, a DNA methyltransferase 3B deficiency and immunodeficiency disease. Clinical immunology. 2003; 109: 17-28.

14. Ren DN, Kim IY, Koh SB, Chang SJ, Eom M, Yi SY, et al. Comparative analysis of thymidylate synthase at the protein, mRNA, and DNA levels as prognostic markers in colorectal adenocarcinoma. Journal of surgical oncology. 2009; 100: 546-52.

15. Banerjee RV, Matthews RG. Cobalamin-dependent methionine synthase. The FASEB journal. 1990; 4: 1450-9.

16. Leclerc D, Campeau E, Goyette P, Adjalla CE, Christensen B, Ross $\mathrm{M}$, et al. Human methionine synthase: cDNA cloning and identification of mutations in patients of the cblG complementation group of folate/cobalamin disorders. Human molecular genetics. 1996; 5: 1867-74.

17. Sharp L, Little J. Polymorphisms in genes involved in folate metabolism and colorectal neoplasia: a HUGE review. American journal of epidemiology. 2004; 159: 423-43.

18. Fredriksen $\AA$, Meyer K, Ueland PM, Vollset SE, Grotmol T,
Schneede J. Large-scale population-based metabolic phenotyping of thirteen genetic polymorphisms related to one-carbon metabolism. Human mutation. 2007; 28: 85665.

19. Lissowska J, Gaudet MM, Brinton LA, Chanock SJ, Peplonska $B$, Welch R, et al. Genetic polymorphisms in the one-carbon metabolism pathway and breast cancer risk: A population-based case-control study and meta-analyses. International journal of cancer. 2007; 120: 2696-2703.

20. Chen K, Song L, Jin MJ, Fan CH, Jiang QT, Yu WP. Association between genetic polymorphisms in folate metabolic enzyme genes and colorectal cancer: a nested case-control study. Zhonghua zhong liu za zhi Chinese journal of oncology. 2006; 28: 429-32.

21. Shi Q, Zhang Z, Li G, Pillow PC, Hernandez LM, Spitz MR, et al. Polymorphisms of methionine synthase and methionine synthase reductase and risk of lung cancer: a case-control analysis. Pharmacogenetics and genomics. 2005; 15: 54755.

22. Sarbia M, Stahl M, Von Weyhern C, Weirich G, PühringerOppermann F. The prognostic significance of genetic polymorphisms (Methylenetetrahydrofolate Reductase C677T, Methionine Synthase A2756G, Thymidilate Synthase tandem repeat polymorphism) in multimodally treated oesophageal squamous cell carcinoma. British journal of cancer. 2005; 94: 203-7.

23. Galbiatti AL, Ruiz MT, Biselli-Chicote PM, Raposo LS, Maniglia JV, Pavarino-Bertelli EC, et al. 5Methyltetrahydrofolate-homocysteine methyltransferase gene polymorphism (MTR) and risk of head and neck cancer. Brazilian Journal of Medical and Biological Research. 2010; 43: 445-50.

24. Zhang FF, Terry MB, Hou L, Chen J, Lissowska J, Yeager M, et al. Genetic polymorphisms in folate metabolism and the risk of stomach cancer. Cancer Epidemiology Biomarkers \& Prevention. 2007; 16: 115-21.

25. Kruszyna $Ł$, Lianeri M, Rydzanicz M, Gajęcka M, Szyfter K, Jagodziński PP, et al. Polymorphic variants of folate metabolism genes and the risk of laryngeal cancer. Molecular biology reports. 2010; 37: 241-7.

26. Suzuki T, Matsuo K, Hasegawa Y, Hiraki A, Wakai K, Hirose K, et al. One-carbon metabolism-related gene polymorphisms and risk of head and neck squamous cell carcinoma: Case-control study. Cancer science. 2007; 98: 1439-46.

27. Ahmed I, Islam M, Arshad W, Mannan A, Ahmad W, Mirza B. High-quality plant DNA extraction for PCR: an easy approach. Journal of applied genetics. 2009; 50: 105-7.

28. Argiris A, Karamouzis MV, Raben D, Ferris RL. Head and neck cancer. The Lancet. 2008; 371: 1695-1709.

29. Lung T, TĂŞCĂU OC, ALMĂŞAN HA, MUREŞAN O. Head and neck cancer, epidemiology and histological aspects-Part 1: A decade's results 1993-2002. Journal of CranioMaxillofacial Surgery. 2007; 35: 120-5.

30. Abdulamir AS, Hafidh RR, Abdulmuhaimen N, Abubakar F, Abbas KA. The distinctive profile of risk factors of nasopharyngeal carcinoma in comparison with other head and neck cancer types. BMC public health. 2008; 8: 400.

31. Parkin DM, Bray F, Ferlay J, Pisani P. Global cancer statistics, 2002. CA: a cancer journal for clinicians. 2005; 55: 74-108. 
32. Llewellyn C, Johnson NW, Warnakulasuriya K. Risk factors for oral cancer in newly diagnosed patients aged 45 years and younger: a case-control study in Southern England. Journal of oral pathology \& medicine. 2004; 33: 525-32.

33. Chen PH, Shieh TY, Ho PS, Tsai CC, Yang YH, Lin YC, et al. Prognostic factors associated with the survival of oral and pharyngeal carcinoma in Taiwan. BMC cancer. 2007; 7: 101.

34. Tai J, Yang M, Ni X, Yu D, Fang J, Tan W, et al. Genetic polymorphisms in cytochrome $\mathrm{P} 450$ genes are associated with an increased risk of squamous cell carcinoma of the larynx and hypopharynx in a Chinese population. Cancer genetics and cytogenetics. 2010; 196: 76-82.

35. Almadori G, Bussu F, Galli J, Cadoni G, Zappacosta B, Persichilli $S$, et al. Serum folate and homocysteine levels in head and neck squamous cell carcinoma. Cancer. 2002; 94: 1006-11.

36. Raval GN, Sainger RN, Rawal RM, Patel JB, Patel BP, Jha FP, et al. Vitamin B. Asian Pacific Journal of Cancer Prevention. 2002; 3: 155-62.

37. Chen LH, Liu ML, Hwang HY, Chen LS, Korenberg J, Shane B, et al. Human methionine synthase cDNA cloning, gene localization, and expression. Journal of Biological Chemistry. 1997; 272: 3628-34.

38. Scott JM, editor Genetic Variation of Homocysteine Metabolism and Atherosclerosis. Nestle Nutrition Workshop Series; 2003; pp: 1-24 : Philadelphia; LippincottRaven; 1999.

39. Dekou V, Gudnason V, Hawe E, Miller GJ, Stansbie D, Humphries SE, et al. Gene-environment and gene-gene interaction in the determination of plasma homocysteine levels in healthy middle-aged men. THROMBOSIS AND HAEMOSTASIS-STUTTGART. 2001; 85: 67-74.

40. Harmon DL, Shields DC, Woodside JV, McMaster D, Yarnell JW, Young IS, et al. Methionine synthase D919G polymorphism is a significant but modest determinant of circulating homocysteine concentrations. Genetic epidemiology. 1999; 17: 298-309.

41. Li YN, Gulati S, Baker PJ, Brody LC, Banerjee R, Kruger WD. Cloning, mapping and RNA analysis of the human methionine synthase gene. Human molecular genetics. 1996; 5: 1851-8.
42. Ma J, Stampfer MJ, Christensen B, Giovannucci E, Hunter DJ, Chen J, et al. A polymorphism of the methionine synthase gene: association with plasma folate, vitamin B12, homocyst (e) ine, and colorectal cancer risk. Cancer Epidemiology Biomarkers \& Prevention. 1999; 8: 825-9.

43. Silaste ML, Rantala M, Sampi M, Alfthan G, Aro A, Kesäniemi YA. Polymorphisms of key enzymes in homocysteine metabolism affect diet responsiveness of plasma homocysteine in healthy women. The Journal of nutrition. 2001; 131: 2643-7.

44. Paz MF, Avila S, Fraga MF, Pollan M, Capella G, Peinado MA, et al. Germ-line variants in methyl-group metabolism genes and susceptibility to DNA methylation in normal tissues and human primary tumors. Cancer research. 2002; 62: 451924.

45. De Capoa A, Musolino A, Della Rosa S, Caiafa P, Mariani L, Del Nonno F, et al. DNA demethylation is directly related to tumour progression: evidence in normal, pre-malignant and malignant cells from uterine cervix samples. Oncology reports. 2003; 10: 545-9.

46. Brothman AR, Swanson G, Maxwell TM, Cui J, Murphy KJ, Herrick J, et al. Global hypomethylation is common in prostate cancer cells: a quantitative predictor for clinical outcome? Cancer genetics and cytogenetics. 2005; 156: 316.

47. Cadieux B, Ching TT, VandenBerg SR, Costello JF. Genomewide hypomethylation in human glioblastomas associated with specific copy number alteration, methylenetetrahydrofolate reductase allele status, and increased proliferation. Cancer research. 2006; 66: 846976.

48. Ehrlich M. DNA methylation in cancer: too much, but also too little. Oncogene. 2002; 21:5400-13.

49. Das PM, Singal R. DNA methylation and cancer. Journal of Clinical Oncology. 2004; 22: 4632-42.

50. Fang JY, Xiao SD. Folic acid, polymorphism of methyl-group metabolism genes, and DNA methylation in relation to $\mathrm{Gl}$ carcinogenesis. Journal of gastroenterology. 2003; 38: 8219. 